\title{
PHYSICAL ACTIVITY AND HEALTH RELATED ENVIRONMENT PREFERENCES AMONG STUDENTS FROM THE LITHUANIAN ACADEMY OF PHYSICAL EDUCATION
}

\author{
Edita Vainienè
}

Lithuanian Academy of Physical Education, Kaunas, Lithuania

Submitted in September, 2010

BACKGROUND: The physical activity preferences (PAP) and attitude towards health's promotion among freshers from different classes while maintaining a constant level of physical activity (PA) intervention.

OBJECTIVE: To determine changes in the PAP of future physical education teachers and health educators.

METHODS: The studies were carried out in 2000 and 2008 year with students from Lithuanian Academy of Physical Education (LAPE). A standardized, self administered questionnaire was filled in by 577 fresher students (244 males and 333 females).

RESULTS: There were fewer students who wanted to attend a special health training course (coping with stress, remedial exercise, healthy nutrition) in 2008 than in 2000 (males $57.8 \%$ and $46.7 \%$, p < 0.1 ; females $84.4 \%$ and $71.2 \%$ $\mathrm{p}<0.02$ respectively). Females showed a more critical view of the environment of the academy than males and mentioned that there were fewer possibilities for healthy nutrition in the academy in 2008 than in $2000(26.1 \%$ and $19.12 \%$ $\mathrm{p}<0.02$ ). After eight years students are using health promotion tools less often in the academy. The number of students who used vigorous and strengthening activities decreased in 2008 comparing with the year 2000 (males 59.2\% and $46.7 \%$; females $47.7 \%$ and $22.5 \% \mathrm{p}<0.001$, respectively). Also fewer of them chose wellness centers (males $27.6 \%$ and $22.8 \%$, females $37.0 \%$ and $11.6 \% \mathrm{p}<0.001$, respectively). There were fewer females who reported having participated in activities which made them sweat and breathe hard (2-3 times/week and more) in 2008 than in $2000\left(c^{2}=49.05\right.$, $\mathrm{p}<0.001)$. The Contingency Coefficient $(\mathrm{C})$, measuring the strength of this association was at .369 .

CONCLUSIONS: The data suggest that there is an increasing need for intervention to promote PA among students who enter the academy and continue studying here.

RECOMMENDATIONS: It is necessary to develop physical activity programs for an integral academy education, mainly in females, avoiding the lowering of physical activity as they move higher at the educational level. Also the plan to increase the number of physical activities and exercises must be included in curricular scenarios, and the use of leisure time must be oriented towards physical activity.

Keywords: Health promotion, gender, identity, fresher students.

\section{INTRODUCTION}

The realities of post modem social life raise new tasks for the system of education and academic communities. The conception of lifestyle acquires significant meaning in the postmodern world of social activity (Giddens, 2000), especially in the world of future physical education teachers and health educators. Thus the everyday activity of future specialists is a sort of preparation for professional activity. We can't imagine the society of knowledge without working educators with qualification who especially promote children's health (Kardelienè, Kardelis, Karanauskiene, \& Šukys, 2009). In postmodern society, a teacher of physical education is not only a conveyor of knowledge and skills, but a person who is a partner, provocative, assuages learning, and allows for finding, knowing and discovering (Barkauskaite, 2006). As catalysts of successful informational societies, teachers must therefore be able to build a special kind of professionalism - a new professionalism, where they can learn to teach in ways in which they were not taught themselves (Hargreaves \& Lo, 2000). Brott and Kajs (2001) underline two levels of the process of becoming a professional: 1) the structural level (education and training), and 2) the level of personal attitudes and standpoints. Augustinaitis (2002) states that a crisis of classic professionalism increases problems of professional identity or the lack of professional identity. The searching for or renewal of identity according to the author becomes irrelevant, since new forms of identity are being built up. These new forms legitimate the postmodern world view, which gives a push to modernity and the dominance of its specialties and, increasingly, to states of discrepancy, pluralism, holism and some uncertainty. Such aspects as communication with members of the academic community, experiencing positive emotions, the organization of studies, student needs, analysis of documents of higher education, which enables students 
to evaluate their rights, could have a great impact on the future career peculiarities and professional image influencing the image of a specialist of physical education and sport in our society (Karanauskienè, Kardelienè, $\&$ Kardelis, 2007). Students represent a particular segment of the adult population who could gain considerable long term benefits from PA. First year students encounter various changes: academic, social, physical, emotional and even cultural in nature (Bray \& Born, 2004). The profession of a physical education teacher and health educator demands from future specialists an acquired view to health and vigor promotion and a healthy lifestyle (Kardelienè, Kardelis, Karanauskienè, $\&$ Šukys, 2009). Therefore, colleges and universities provide an important setting for intervention aimed at assisting young adults in developing and maintaining not only health promoting behaviors but also an opportunity to use an environment's services. It must be taken into account that PA should be a normal part of growing up for young people (Bray \& Born, 2004). According to the 2007 American Heart Association (AHA) and the American College of Sports Medicine (ACSM) in order to promote and maintain health it is recommended for all healthy adults aged 18-65 years to fulfill the need for moderate intensity aerobic physical activity for a minimum of $30 \mathrm{~min}$ on five days each week or vigorous intensity aerobic activity for a minimum of $20 \mathrm{~min}$ on three days each week. Also combinations of moderate and vigorous intensity activity can be performed to meet this recommendation. Europe consists of more than 60 nations of diverse ethnic, cultural, religious, political and socio-economic background. The health benefits of physical activity assure that physical activity is included in national health policies across the continent, but only about one third of the countries have physical activity policies and only a small proportion of them seem to use recommended levels of physical activity for defining and evaluating goals at the policy level. Plus, many of the existing national physical activity recommendations are based on the 1995 U.S. Centers for Disease Control and Prevention (CDC) and ACSM recommendations, and they may need to be updated based on the newest evidence as reviewed for the U.S. Department of Health and Human Services (U. S. DHHS) 2008 physical activity recommendations (Oja, Bull, Fogelholm, Martin, \& Brian, 2010). Unfortunately as more recent data suggest that $80 \%$ females and $53 \%$ males wished to go in for sports only once a week. First year students, especially females are not determined to go in for regular recommended PA (Poteliūnienè, Kapustinskienè, \& Kepežienė, 2006). Petkevičienė et al. (2002) showed that Lithuanian students' PA is insufficient and it declines throughout the period of their studies: only a third of students, 4-6 times a week, were engaged in VPA, every tenth student was physically active less than once a week. Therefore, if PA is altered during a transition, there may be important acute physical and psychological consequences for first year students. Perhaps the most convincing fact is that a decline in PA experienced during the first few months of university may lead to a pattern of inactivity that persists through out one's university years and beyond (Bray \& Born, 2004). Universities play an important role in socializing and preparing students for work and developing an early and accurate professional identity. A further review of scientific literature showed that the formation of professional identity is very important for future specialists, but it is more important to discuss student's PA not only as professional identity's manifestation, but also as one of health's elements.

Students from LAPE have a unique opportunity to study in the areas of physical education and sports science. LAPE as an institution also attaches great importance/pays great attention to organizing various sports activities and events for students so that they can successfully combine studies with sport activity in a chosen kind of sport. We may presume that students who are physically active and regularly participate in sports should be well developed personally and could become better role models for children. Before academy students are directed toward physical activity and sport it would be proper to set up the objective of this study: to determine the changes in PAP of future physical education teachers and health educators.

\section{METHODS}

\section{Participants}

Students from the Lithuanian Academy of Physical Education (LAPE) filled in a standardized questionnaire created by the scientists from Kaunas University of Medicine, Lithuania, and Bielefeld University, Germany (Petkevičienė, Kardelis, Misevičienè, \& Petrauskas, 2002). The surveys were carried out in the years 2000 and 2008. The research sample in the first survey (2000) consisted of 263 students ( 105 males and 158 females). In the second survey (2008) there were 314 students (139 males and 175 females). The subjects were first year students who in the future will be physical education teachers and health educators.

\section{Measures}

Socio-demographic variables were gender, maternal and parental education, and marital status, as well as residence.

\section{PA}

General questions about levels of regular PA with respect to frequency, intensity and duration were given to students. Students had to report how many times during a usual week they participated in moderate physical 
activity (MPA), (household chores, yard work, walking the dog, etc.) for at least 20-30 minutes that did not make them sweat or breathe hard. Another question concerning VPA was given to students by asking how often they participated in VPA, for at least 20 minutes that made them sweat or breathe hard. According to the weekly frequency of VPA, students were divided into two groups: physically more active (by 2-3 times a week and more) and less physically active (once a week or less). We were also interested in students' usage of vigorous and strengthening activities.

\section{Health promotion}

We were interested in students' request for a special health course (coping with distress, remedial exercise, giving up smoking, healthy nutrition) at the academy. Students also had to answer about a no smoking policy, healthy nutrition, seats and classrooms, accommodation and climate. They had to point to which health promotion implements they know and use.

\section{The academy's environment and conditions}

We asked students how they feel about different academy places (generally, library, classes, classrooms, laboratories, dining hall, and the gym). The variables related to feelings in any particular place were evaluated on a 5 point scale from "very good" to "very bad". The total sum was calculated. According to the sum we divided students into two groups: 1) feeling very good, 2) feeling very bad. We also asked students how they like: the academy's elective studies, sports activities, cultural activities, technical opportunities, and the dining hall's food as well as the academy's location and environment. The variables related to the academy's conditions were evaluated on a 5 point scale from "very good" to "very bad". The total sum was calculated. According to the sum we divided students into two groups: 1) those who assessed very good conditions at the academy, 2) those who assessed the academy's conditions as being very bad.

\section{Professional career}

We wondered about students' professional careers. Have they planned out their professional career after finishing their studies? Are they sure about the success of those professional career plans?

\section{Procedure}

The survey procedures were designed to protect students' privacy. Participants were informed of the nature of the study and were told that their participation was completely voluntary and confidential. They agreed to participate in the study and no incentives were provided. The survey was typically administered in classes, with response rates in the year 2000 exceeding $80.6 \%$ and in the year 2008 year exceeding $80.5 \%$.

\section{Statistical processing}

The relationship between variables was described by using the chi square $\left(\chi^{2}\right)$ criterion and significance level (p), while the strength of this relationship was determined by Pearson's contingency coefficient (C). In terms of this Contingency Coefficient we distinguished among small $(0.10<C<0.29)$, medium $(0.30<C<0.49)$ and large effects $(>0.50)$. Testing of statistical hypotheses significance was set at $p \leq 0.05$. The data was analyzed using the statistical software SPSS 14.0.

\section{RESULTS}

\section{Socio-demographic variables}

There were 263 students in the sample from the year 2000 (105 males and 158 females). The sample in the year 2008 consisted of 314 students (139 males and 175 females). The students were in the first course. In the future they will be physical education teachers and health educators. An analysis of two studies showed that males' marital status did not differ. In the years 2000 and 2008, the majority of males were unmarried $(96.4 \%$ and $93.3 \%$ respectively), married $(1.0 \%$ and $0.7 \%)$ and there was virtually no marital cohabitation $(0.4 \%$ and $0.0 \%)$. A clearer cut was seen in the females' results. If in the year $20007.6 \%$ were married, then in the year 2008 only $1.7 \%$ ( $p<0.04$ were married). There were fewer students in the year 2008 than in the year 2000 who mentioned living with their parents $(62.7 \%$ and $50.6 \%$; $\mathrm{p}<0.02$ respectively) and many more living in a hall of residence ( $13.3 \%$ and $33.5 \%$; $<0.001$ respectively). In the year 2008 according to gender differences, there were more males who lived with their parents $(49.5 \%$ and $56.8 \%$ ) and many more living in a hall of residence (31.6\% and $27.6 \%)$. In the year 2008 fewer males rented a flat than in the year 2000 year $(19.0 \%$ and $15.2 \%$ respectively) but there were more females who rented a flat in the year 2008 (17.1\% and 22.8\%). Comparing the alteration of students' demographic characteristics according to parental (mother, father) education we divided students into two groups: students whose parents have got higher education and students whose parents have got less than higher education. In the year 2008 there were fewer males and females whose mothers had a higher education (males $63.8 \%$ and $57.7 \%$; females $62.8 \%$ and $59.5 \%$ respectively). More obvious differences were seen in the group of females according to parental education in the year 2008. There were fewer females who mentioned that their father had a higher education in the year 2008 (54.8\% and 40.5\%; $\mathrm{p}<0.01$ respectively).

\section{PA}

The psychological and physiological benefits associated with PA may be notably pertinent to the acad- 
emy population. Our study showed that students were engaged in moderate physical activity (MPA), (household chores, yard work, walking the dog, etc.) $14.1 \pm 0.6$ time a week. However comparing studies from the years 2000 and 2008 we noticed the decline of such a form of activity among students of the academy. In the year 2000 males were engaged in MPA $17.5 \pm 1.35$ times a week and in the year 2008 only $14.9 \pm 1.2$ times a week ( $p<0.08)$. We noticed an analogical situation in females who engaged in MPA: in the year $200014.1 \pm 1.4$ times a week and in the year $200811.4 \pm 0.8$ times a week. Comparing the results, in the year 2008 there were fewer students in both groups who were engaged in MPA (at least 3 times a week), (males $79.7 \%$ and $81.9 \%$; females $42.5 \%$ and $51.0 \% ; \mathrm{c}^{2}=44.256, \mathrm{p}<0.001$ respectively). The contingency coefficient (C), measuring the strength of the association was at .352 .

We surveyed students about the frequency of their participating in "vigorous" and "less vigorous" exercise. According to the weekly frequency of vigorous exercise, students were divided into two groups: those exercising 2-3 times a week and more and the other group, which exercised once a week or less. Comparing the results of the years 2000 and 2008, females were less active (accordingly $71.2 \%$ and $42.5 \%$; $\mathrm{c}^{2}=49.05, \mathrm{p}<0.001$ ). The contingency coefficient (C), measuring the strength of the association was at .369 . In the males' group we noticed fewer negative changes $(87.6 \%$ and $81.8 \%)$.

In the year 2008 there were fewer students who were engaged in the usage of vigorous and strengthening activities (males $67.4 \%$ and $76.2 \%$, females $28.7 \%$ and $43 \%$; $\mathrm{c}^{2}=49.517, \mathrm{p}<0.001$ respectively). The $\mathrm{C}$, measuring the strength of the association was at .370 .

\section{Health promotion}

Students have great opportunities to plan and carry out health promotion at universities, but they do not always take advantage of such opportunities. It is interesting to note that there were fewer students who wanted to attend a special health training course (coping with distress, remedial exercise, giving up smoking, healthy nutrition) in the year 2008 than in the year 2000 (males $57.8 \%$ and $46.7 \%$; $p<0.1$; females $84.4 \%$ and $71.2 \%$; $\mathrm{p}<0.02$, respectively). Despite these results, many more females than males requested a special health training course. We were interested in students' attitudes toward health promotion. Students had their opinions about the academy's environment related to health (TABLE 1).

TABLE 1 shows that males were more positive in evaluating the academy's environment related to health. Females showed a more critical view of the environment of the academy than males and mentioned that there were fewer possibilities for healthy nutrition in the academy in the year 2008 than in the year 2000. Females also showed a more critical view of the architecture of the academy in the year 2008.
After eight years there were also changes in the usage of health promotion elements. The facts suggest that the changes were not so positive, especially in the female group (TABLE 2).

Comparing studies from the years 2000 and 2008, the results in TABLE 2 revealed the decline of vigorous physical activity (VPA) especially in the females' group. There were fewer males who choose sport sessions and exercises as their health promotion implement in the year 2008. In the year 2008, students were less engaged in wellness centers. The results show the tendencies of fresher students' to PA's decrement.

\section{Academy's environment and conditions}

Given the fact that positive health benefits are bonded with the competitive, achievement oriented environment of academy study, the evidence supports that fresher students may have a great deal to gain in terms of health and well being, also positive attitudes toward their environment. Their environment is very important for students, because they spend most of their time at the academy. We were interested in seven places of the academy (generally, the library, classes, classrooms, laboratories, dining hall and the gym). We divided students into two groups according to their feelings about the academy's accommodations. Here we present only a group of students who evaluated their feelings as "very good" or "good" (TABLE 3 ).

TABLE 3 shows that a majority of the students generally feel very well at the academy. Males felt somewhat uncomfortable at the dining hall (negative changes) and library (positive changes). Females felt slightly uncomfortable at the library, laboratories (negative changes) and dining hall (positive changes). In the year 2008, fewer females felt very good at the gym comparing to the year 2000.

We wondered how students assess the academy's environment, elective studies, sport activities, cultural activities, technical opportunities, and the dining hall's food. According to the assessment of the academy's conditions we divided students into two groups, but in TABLE 4 we present only the students who assessed the academy's conditions as being very good.

TABLE 4 shows that the majority of students felt favorably toward the academy's location and environment. But in the year 2008, females were more critical of the academy's location and environment ( $p<0.06)$. Students felt also favorably about technical opportunities, but the males' view was more stable and they had a more positive attitude than females. Changes were positive, hence we can assume that the situation at the academy is getting better according to the technical opportunities. In the year 2008 students found elective studies at the academy and other universities to be more attractive. Positive alteration was seen in cultural and 
TABLE 1

Alteration of students opinion about academy's environment, related with health (\%)

\begin{tabular}{|l|c|c|c|c|}
\hline \multirow{2}{*}{ Affirmations } & \multicolumn{2}{|c|}{ Males } & \multicolumn{2}{c|}{ Females } \\
\cline { 2 - 5 } & $\mathbf{2 0 0 0}$ year & $\mathbf{2 0 0 8}$ year & $\mathbf{2 0 0 0}$ year & $\mathbf{2 0 0 8}$ year \\
\hline There should be realizable a no smoking policy at the academy & 57.7 & 66.4 & 73.9 & 68.8 \\
\hline There are enough opportunities for healthy nutrition at the academy & 23.3 & 34.1 & 26.1 & 19.1 \\
\hline Seats are comfortable enough at the academy & 37.9 & $59.9^{* *}$ & 48.4 & 53.2 \\
\hline To sit in the classrooms are comfortable enough & 45.2 & $67.9^{* *}$ & 44.9 & $55.8^{*}$ \\
\hline The architecture of the academy is attractive & 69.9 & 72.3 & 78.3 & 71.3 \\
\hline Don't like the accommodation climate (temperature, damp) & 48.5 & 50.4 & 53.2 & 52.3 \\
\hline
\end{tabular}

Legend: * $-\mathrm{p}<0.05$ comparing 2000 and 2008 information $\left(\chi^{2}=7.470, \mathrm{df}=1, \mathrm{C}=.107\right)$; ** $-\mathrm{p}<0.001$ comparing 2000 and 2008 information $\left(\chi^{2}=15.283, \mathrm{df}=1, \mathrm{C}=.122\right)$

TABLE 2

Alteration of the usage of the health promotion implements at the academy (\%)

\begin{tabular}{|l|c|c|c|c|}
\hline \multirow{2}{*}{ Implements } & \multicolumn{2}{|c|}{ Males } & \multicolumn{2}{c|}{ Females } \\
\cline { 2 - 6 } & $\mathbf{2 0 0 0}$ year & $\mathbf{2 0 0 8}$ year & 2000 year & $\mathbf{2 0 0 8}$ year \\
\hline Sport session, exercises & 59.2 & 46.7 & 47.7 & $22.5^{*}$ \\
\hline Wellness centers (aerobics, trainers) & 27.6 & 22.8 & 37.0 & $11.6^{*}$ \\
\hline Psychological health & 2.0 & 4.4 & 1.3 & 2.9 \\
\hline
\end{tabular}

Legend: * $-\mathrm{p}<0.001$ comparing 2000 and 2008 information $\left(\chi^{2}=22.259, \mathrm{df}=2, \mathrm{C}=.259\right)$

TABLE 3

Students who feel very well or well at the academy (\%)

\begin{tabular}{|l|c|c|c|c|}
\hline \multirow{2}{*}{ Academy's accommodations } & \multicolumn{2}{|c|}{ Males } & \multicolumn{2}{c|}{ Females } \\
\cline { 2 - 6 } & $\mathbf{2 0 0 0}$ & $\mathbf{2 0 0 8}$ & $\mathbf{2 0 0 0}$ & $\mathbf{2 0 0 8}$ \\
\hline Generally & 96.2 & 100 & 100 & 98.3 \\
\hline Library & 85.1 & 88.8 & 86.5 & 82.4 \\
\hline Classes & 95.6 & 98.2 & 97.0 & 95.1 \\
\hline Labsoratories & 85.5 & $94.6^{*}$ & 92.8 & 93.0 \\
\hline Dining hall & 88.9 & 91.8 & 88.0 & 82.1 \\
\hline Gym & 77.3 & 72.6 & 56.4 & 63.8 \\
\hline
\end{tabular}

Legend: * $-\mathrm{p}<0.05$ comparing 2000 and 2008, males $\left(\chi^{2}=7.847, \mathrm{df}=1, \mathrm{C}=.033\right)$; ** $-\mathrm{p}<0.01$ comparing 2000 and 2008 , females $\left(\chi^{2}=11.547, \mathrm{df}=1, \mathrm{C}=.149\right)$

TABLE 4

Students who assess academy's conditions as being very good (\%)

\begin{tabular}{|l|c|c|c|c|}
\hline \multirow{2}{*}{ Conditions } & \multicolumn{2}{|c|}{ Males } & \multicolumn{2}{c|}{ Females } \\
\cline { 2 - 5 } & $\mathbf{2 0 0 0}$ & $\mathbf{2 0 0 8}$ & $\mathbf{2 0 0 0}$ & $\mathbf{2 0 0 8}$ \\
\hline Dining hall's food & 42.1 & 51.7 & 40.2 & 49.1 \\
\hline Technical opportunities (copy, internet, computers) & 72.3 & 82.4 & 54.3 & $74.7^{*}$ \\
\hline Cultural activity & 69.8 & 74.0 & 69.0 & 77.6 \\
\hline Sport activity & 90.6 & 90.7 & 87.8 & 90.2 \\
\hline Elective studies (at the academy and other universities) & 87.5 & 91.4 & 80.0 & 89.4 \\
\hline Academy's location and environment & 94.0 & 97.2 & 100 & 96.2 \\
\hline
\end{tabular}

Legend: * $-\mathrm{p}<0.05$ comparing 2000 and 2008 information $\left(\chi^{2}=5.203, \mathrm{df}=1, \mathrm{C}=.179\right)$ 
sport activities at the academy. Less acceptance in both studies was attained by the canteen's food, although the situation in the year 2008 was better. According to the total score of the students answers about the academy's conditions, we formed two groups. In the year 2000 there were students who were satisfied $(47.4 \%$ of the males and $44.4 \%$ of the females) and who are not satisfied ( $55.6 \%$ of the males and $52.6 \%$ of the females). In the year 2008 - there were students who were satisfied (50.6\% of the males and $56.6 \%$ of the females) and who were not satisfied $(49.4 \%$ of the males and $43.4 \%$ of the females) with the academy's conditions.

\section{Professional career}

Answers to questions about their professional careers showed that the majority of fresher students have not already planned out their professional careers after graduation from the academy, considering that, in the year $2000,36.5 \%$ of the males mentioned that they had not planned out their professional career. In the year $2008,47.5 \%$ of the males mentioned such contemplation. In the females' group there were more positive changes regarding their planned out professional careers. In the year $2000,63.5 \%$ of the females did not plan out their professional career and in the year 2008 there were fewer females with such thoughts $(52.5 \%)$. Not so confident with the success of their future professional career plans in the year 2000 were $40.8 \%$ of the males, $59.2 \%$ of the females and in the year $2008,44.3 \%$ of the males and $55.7 \%$ of the females.

\section{DISCUSSION}

Students are an important part of society and it is significant to know what are the preferences of the health environment and physical activity of students from LAPE who in the future will be physical education teachers and health educators. Our study showed that the majority of our future specialists were not married. In line with our results Arnett (2005) states that the rise in the typical ages of entering marriage and parenthood is due to the increase in the years devoted to pursuing higher education. Young people see adulthood and its obligations in quite a different way. For them it means security and stability, but also represents the end to the freedom of emerging adulthood. Our study showed that in the year 2008 there were fewer males and females whose mothers had a higher education. Other studies (Karanauskienè \& Kardelis, 2005) found that students who had at least one parent with a higher education were more critical about what they were learning than their academy colleagues and they were more positive about the possibilities of personal accomplishment. We can make the assumption that parental education is a very important element which can contribute to students' educational aspirations and social integration. This situation requires further study. The physical activity level is not only the most variable component of total daily energy expenditure, but we have to take into account that it is also a behavior and a component of one's lifestyle. Although students from LAPE are more physically active than students from other Lithuanian institutions of higher learning (Petrauskas, 2004), an 8 year period has shown declining PA especially in the females' group. In recent years, tendencies to a diminishing volume of physical education as a subject have been shown. It hardly finds a place in education plans and study programs, although the physical condition of children and youth and their health indices are becoming worse and worse. The PA of students in their leisure time is insufficient and it is diminishing even more in their successive years of study (Poteliūnienè, 2010). Comparing our results with other studies, we found that among fresher students from Sweden, males reported exercising 4 or more times a week and females exercised 2 to 3 times a week (Vaez \& Laflamme, 2003). Our students from LAPE were more physically active $(62.2 \%)$ than students from other Kaunas universities (52.8\%), (Petkevičienè, Kardelis, Misevičienè, \& Petrauskas, 2002). In line with our results Grinienè and Zachovajevas (2008) noticed that half of the respondents practiced sports 4 hours and more per week in the years 2000 and 2007. Of the respondents, 57.7\% practiced sports during the semester in 2007 (42.6\% in $2000)$, the percentages of those who trained in sports clubs was 32.2 and $36.0 \%$, respectively. Bray and Born (2004) remarked that students who were active during their transition to the university reported higher levels of vigor than insufficiently active students. Those students who had become insufficiently active during this transition reported lower levels of vigor and higher levels of fatigue. Further research is needed. According to the 2007 version of AHA and the ACSM, to promote and maintain health it is recommended for all healthy adults. We see that students, especially the females of LAPE, were not behaving according to those PA recommendations. Females were less likely to participate in moderate to vigorous exercise than were males. This was consistent with previous research on physical inactivity and gender (Petkevičienè, Kardelis, Misevičienè, \& Petrauskas, 2002; Petrauskas, 2004). Our study showed that in the year 2008, fewer students wanted to take part in the special training course. Females were more interested in such a training course (coping with distress, remedial exercise, giving up smoking, healthy nutrition) than males from LAPE. Our results show that for LAPE students, especially females in the year 2008 it becomes more difficult to follow the guidelines. According to recent research, students who study the biomedical sciences and those who were studying social sciences and humanities had more need of and interest in the health promotion 
course than students of engineering (Petrauskas, 2004). Universities' environments and conditions are the most important of studies' components which stimulate students to obtain knowledge properly as well as those skills which are required by a chosen profession. Our results showed that there were some positive changes in evaluating an academy's environment related to health. However females were more critical of the possibilities for healthy nutrition and the academy's architecture than males. Another researcher suggests (Petrauskas, $2004)$ that less than half of the students $(42.1 \%$ of the males and $36.2 \%$ of the females) benevolently evaluated the possibilities for healthy nutrition. The majority of future specialists from LAPE generally felt very well at the academy, however there were some places where students felt less comfortable: the dining hall, laboratories, the gym (especially females), and the library. Petrauskas (2004) also found that females in the gym felt worse than males. In line with our results Kardeliene and colleagues (2009) noticed that students with a strong sports identification feel better at the academy. Students believe that the conditions for learning are good enough, if they are able to make use of them. However more of them were not satisfied with the services of the library ( $48.7 \%$ compared to $14.2 \%$ satisfied students, $p<0.005$ ). Students from Vilnius University (VU) were much more pessimistic about conditions for their studies: the necessary books are not always available in the libraries, the possibilities of using modern information technologies at the university were very limited, etc. (Kanopienè \& Tureikytè, 2002).

Students from LAPE are prepared to be sport coaches and teachers of physical education and only some of them choose the career of a sporter, which means their professional identification might be rather different. Our study results pointed to the fact that students from LAPE in the first course were thinking about their future profession and planning their future career. However in the year 2008 more students had more doubts and uncertainty about their future career.

We can assume that the main role in the process of professional identification is played by a student's perception of their own preferences of a healthy environment and physical activities' benefits and it is very important to create educational environments and to maintain students' positive characteristics in this process.

\section{CONCLUSIONS}

This investigation has given some insight into how students feel and evaluate the academy's conditions and environment and into students thoughts about their future careers. The decrement of PA allows us to think about intervention programs. It is very important to create conditions for students so they may know better the specificity of their profession field (both positive and negative aspects). It is advisable to plan longitudinal cohort research of future physical education teachers and health educators from their first year till graduation.

\section{RECOMMENDATIONS}

It is necessary to develop physical activity programs for an integral academy education, mainly in females, avoiding the lowering of physical activity as they move higher at the educational level. Also to increase the number of physical activities and exercises, they must be included in curricular scenarios, and use of leisure time must be oriented towards physical activity.

\section{LIMITATIONS}

The present study has some limitations that should be taken into account. The study had a cross sectional design. Furthermore, the self reporting method for data collection was used. The findings do not identify causes, but only associations. Nevertheless, the study shows that there is decreasing physical activity, especially in the females' group and this fact should be taken into account by health educators and other specialists.

\section{REFERENCES}

Arnett, J. J. (2005). The developmental context of substance use in emerging adulthood. Journal of Drug Issues, 35, 235-253.

Augustinaitis, A. (2002). Trans-disciplinary learning structure of knowledge society. Information Sciences, 23, 39-51.

Barkauskaitè, M. (2006). Students' activation at the pedagogical process of students. Academe Educology, 59(2), 416-427.

Bray, S. R., \& Born, H. A. (2004). Transition to university and vigorous physical activity: Implications for health and psychological well being. Journal of American College Health, 52, 181-188.

Brott, P., \& Kajs, L. (2001). Developing the professional identity of first year teachers through a "Working Alliance". Retrieved 19. 10. 2010 from the World Wide Web: http://www.alt- teachercert.org/Working\%20Alliance.html

Giddens, A. (2000). Modernity and self identity. Self and society in the late modern age. Vilnius: Pradai.

Grinienè, E., \& Zachovajevas, P. (2008). Alternation of social integration and attitudes towards health 
among the students at Lithuanian Academy of Physical Education. Education, Physical Training, Sport, 2(69), 40-46.

Hargreaves, A., \& Lo, L. N. K. (2000). Professionalism in teaching the paradoxical profession: Teaching at the turn. Prospects, 114(2), 1-16.

Kardelienè, L., Kardelis, K., Karanauskienè, D., \& Šukys, S. (2009). Identification of would be specialists in physical education and sports: Academic, athletic and professional. Lithuanian Academy of Physical Education: LAPE press.

Kanopienè, V., \& Tureikyte, D. (2002). The attitude of Vilnius university students towards studies. Philosophy, Sociology, 1, 68-77.

Karanauskienè, D., \& Kardelis, K. (2005). The relationship between students' academic identity and academic achievements. Social Sciences, 1(47), 62-70.

Karanauskienè, D., Kardelienè, L., \& Kardelis, K. (2007). Would be specialist's identification with student's role as a precondition to a professional career? Education, Physical Training, Sport, 1(46), 16-21.

Petkevičienė, J., Kardelis, K., Misevičienė, I., \& Petrauskas, D. (2002). Links between physical activity, harmful habits and profile of studies among students of Kaunas universities. Education, Physical Training, Sport, 4(45), 77-83.

Petrauskas, D. (2004). Assessment of links between subjective health, emotional status and health behavior among students of Kaunas universities. Doctoral dissertation, KMU, Kaunas.

Poteliūniene, S. (2010). Factors, affecting students "physical development and athletes training". Review. Social sciences, Educology (07S). Vilnius.

Poteliūnienè, S., Kapustinskienè, N., \& Kepežienė, N. (2006). Physical body condition of first year students and their need for physical activeness regarding to the social aspect (place of residence). Pedagogy, 81, 69-75.

Oja, P., Bull, F. C., Fogelholm, M., Martin, B., \& Brian, W. M. (2010). Physical activity recommendations for health: what should Europe do? BMC Public Health, 10(10), 1-5.

\section{POHYBOVÉ AKTIVITY \\ A PREFERENCE PROSTŘEDÍ SPOJENÉ SE ZDRAVÍM \\ U STUDENTŮ LITEVSKÉ AKADEMIE TĚLESNÉ VÝCHOVY \\ (Souhrn anglického textu)}

VÝCHODISKA: Preference pohybových aktivit (PPA) a podpora zdravého životního stylu mezi studenty 1 . ročníků různých oborů při současném udržování konstantní úrovně intervence v pohybové aktivitě (PA).

CÍL: Určit změny v PPA u budoucích učitelů TV a zdravotních poradců.

METODY: Studie byly prováděny v letech 2000 a 2008 u studentů Litevské akademie tělesné výchovy (LAPE). Standardizovaný, samostatně vyplňovaný dotazník odevzdalo 577 studentů 1. ročníků (244 mužů a 333 žen).

VÝSLEDKY: V roce 2008 bylo méně studentů, kteří chtěli navštěvovat speciální kurzy zdravotně orientovaného tréninku (zvládání stresu, rehabilitační cvičení, zdravá výživa), než tomu bylo v roce 2000 (muži 57,8 \%, resp. $46,7 \%$, p < 0,1; ženy $84,4 \%$, resp. $71,2 \%$ p $<0,02$ ). Ženy prokázaly kritičtější pohled na prostředí akademie než muži a uvedly, že v roce 2008 je na akademii méně možností zdravého stravování než v roce 2000 (26,1\% oproti $19,12 \% \mathrm{p}<0,02)$. Po osmi letech studenti akademie využívají nástroje podpory zdravého životního stylu méně často. Počet studentů využivajících v roce 2008 energické a posilující činnosti se oproti roku 2000 snížil (muži 59,2\%, resp. 46,7\%; ženy 47,7\%, resp. 22,5\% $\mathrm{p}<0,001)$. Menši počet si také vybíral wellness centra (muži $27,6 \%$, resp. $22,8 \%$; ženy $37,0 \%$, resp. $11,6 \%$ $\mathrm{p}<0,001)$. V roce 2008 bylo méně žen, jež uvedly, že se účastní aktivit, při nichž se potí a rychleji dýchají (2-3× za týden a více), než tomu bylo v roce 2000 $\left(c^{2}=49,05, p<0,001\right)$. Koeficient kontingence $(C)$ měrící sílu tohoto spojení byl 0,369 .

ZÁVĚRY: Výsledky naznačují, že vzrůstá potřeba intervence vedoucí $\mathrm{k}$ podpoře PA mezi studenty, kteří přicházejí na akademii a pokračují zde ve studiu.

DOPORUČENÍ: Zejména u žen je nezbytné připravit programy pohybových aktivit pro integrovanou výuku na akademii, čímž by se omezilo snižování objemu pohybových aktivit úměrné tomu, jak studenti postupují do dalších ročníků. Plán na zvýšení objemu pohybových aktivit a cvičení musí být zahrnut také do studijního plánu a využití volného času se musí orientovat na pohybové aktivity.

Klícová slova: podpora zdravého životního stylu, gender, identita, studenti 1. ročníků. 


\section{Mgr. Edita Vainienè}

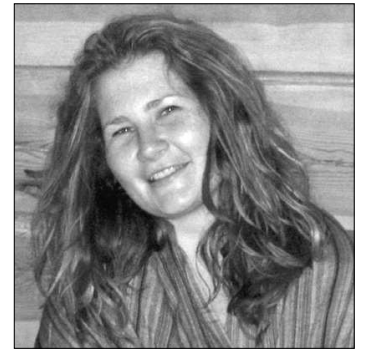

Lithuanian Academy of Physical Education

Sports and Movement Science Center

Sporto 6

44221 Kaunas

Lithuania

\section{Education and previous work experience}

2008 - Ph.D. student in Social Sciences: Physical Education, Motor Learning and Sport, Sports and Movement Science Center.

2001-2003 - Master of Sport (psychology), Sports Education faculty.

\section{Scientific orientation}

Psychosocial and educational aspects of physical activity and health, identity of specialists of physical education and sport, sense of coherence.

\section{First-line publications}

Kardjalis, K. K., \& Eidimtaite, E. N. (2006). Vzaimnosvjaz miezhdu pokazateljami psichosocialnovo zdorovja i motivacii k uczjobe. Voprosy psichologii, 2, 24-30.

Vainienè, E., \& Kardelis, K. (2008). Links of physical activity of youth school pupils with their learning motivation, self respect and social integration. Education. Physical training. Sport, 1(68), 100-107.

Vainienè, E., \& Kardelis, K. (2008). Links of youth school pupil's physical activity with their learning motivation, self-esteem and social integration. In Current issues and new ideas in sport science: 2nd International Scientific Conference (thesis) (p. 147). Kaunas: Lithuanian Academy of Physical Education.

Vainienè, E. (2008). Psychosocial health's and learning motivation's indicators connection with physical activity and their comparative analysis. In Current issues and new ideas in sport science: 2nd International Scientific Conference (thesis) (p. 146). Kaunas: Lithuanian Academy of Physical Education.

Vainienè, E., \& Kardelis, K. (2009). Relations between learning motivation and psychosocial health indices of pupils in higher forms. Journal of Young Scientists, 1(22), 193-199.

Vainienè, E. (2010). Peculiarities of sexual life of students from Lithuanian Academy of Physical Education. In Science for Human Health: 3rd National Scientific Conference (thesis) (p. 29). Lithuanian University of Health Sciences.

Vainienè, E., \& Kardelis, K. (2010). Physical activity preferences and fluctuation among the students at the Lithuanian Academy of Physical Education. Acta Universitatis Palackianae Olomucensis. Gymnica, 40(3), 63. 